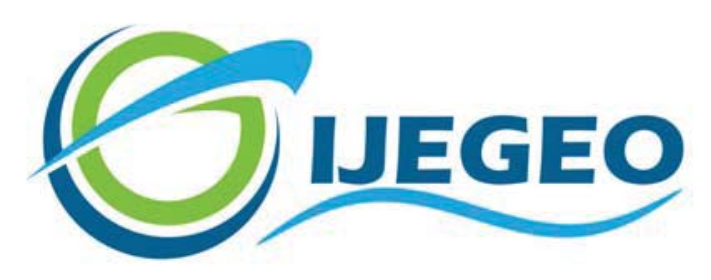

International Journal of Environment and Geoinformatics (IJEGEO) is an international, multidisciplinary, peer reviewed, open access journal.

\title{
Geospatial Modelling Geomorphic Typologies of the Binahaan River, Philippines
}

\section{Kezia Faith OBBUS, James Nicko FLORDELIS, Earl Godfred VELOS, Numeriano Amer GUTIERREZ}

\author{
Chief in Editor \\ Prof. Dr. Cem Gazioğlu \\ Co-Editors \\ Prof. Dr. Dursun Zafer Şeker, Prof. Dr. Şinasi Kaya, \\ Prof. Dr. Ayşegül Tanık and Assist. Prof. Dr. Volkan Demir
}

Editorial Committee (December 2021)

\begin{abstract}
Assoc. Prof. Dr. Abdullah Aksu (TR), Assit. Prof. Dr. Uğur Algancı (TR), Prof. Dr. Bedri Alpar (TR), Assoc. Prof. Dr. Aslı Aslan (US), Prof. Dr. Levent Bat (TR), Prof. Dr. Paul Bates (UK), İrşad Bayırhan (TR), Prof. Dr. Bülent Bayram (TR), Prof. Dr. Luis M. Botana (ES), Prof. Dr. Nuray Çağlar (TR), Prof. Dr. Sukanta Dash (IN), Dr. Soofia T. Elias (UK), Prof. Dr. A. Evren Erginal (TR), Assoc. Prof. Dr. Cüneyt Erenoğlu (TR), Dr. Dieter Fritsch (DE), Prof. Dr. Çiğdem Göksel (TR), Prof.Dr. Lena Halounova (CZ), Prof. Dr. Manik Kalubarme (IN), Dr. Hakan Kaya (TR), Assist. Prof. Dr. Serkan Kükrer (TR), Assoc. Prof. Dr. Maged Marghany (MY), Prof. Dr. Michael Meadows (ZA), Prof. Dr. Nebiye Musaoğlu (TR), Prof. Dr. Masafumi Nakagawa (JP), Prof. Dr. Hasan Özdemir (TR), Prof. Dr. Chryssy Potsiou (GR), Prof. Dr. Erol Sarı (TR), Prof. Dr. Maria Paradiso (IT), Prof. Dr. Petros Patias (GR), Prof. Dr. Elif Sertel (TR), Prof. Dr. Nüket Sivri (TR), Prof. Dr. Füsun Balık Şanlı (TR), Prof. Dr. Uğur Şanlı (TR), Duygu Ülker (TR), Prof. Dr. Seyfettin Taş (TR), Assoc. Prof. Dr. Ömer Suat Taşkın (TR), Assist. Prof. Dr. Tuba Ünsal (TR), Dr. Manousos Valyrakis (UK), Dr. İnese Varna (LV), Dr. Petra Visser (NL), Prof. Dr. Selma Ünlü (TR), Assoc. Prof. Dr. Oral Yağcı (TR), Prof. Dr. Murat Yakar (TR), Assoc. Prof. Dr. İ. Noyan Yılmaz (AU); Assit. Prof. Dr. Sibel Zeki (TR)
\end{abstract}

Abstracting and Indexing: TR DIZIN, DOAJ, Index Copernicus, OAJI, Scientific Indexing Services, International Scientific Indexing, Journal Factor, Google Scholar, Ulrich's Periodicals Directory, WorldCat, DRJI, ResearchBib, SOBIAD 


\title{
Geospatial Modelling Geomorphic Typologies of the Binahaan River, Philippines
}

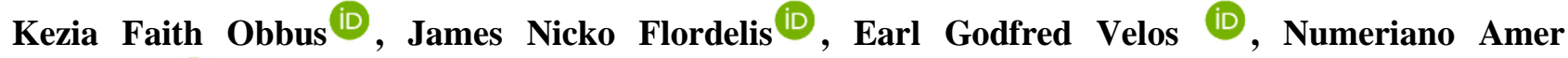 \\ Gutierrez $^{*}$ iD
}

Center for Research in Science and Technology, Philippine Science High School - Eastern Visayas Campus, Palo, PHILIPPINES

* Corresponding author: Numeriano Amer Gutierrez

Received 03.04.2021

E-mail: ngutierrez@evc.pshs.edu.ph

Accepted 23.08.20201

How to cite: Obbus, et al. (2021). Geospatial Modelling Geomorphic Typologies of the Binahaan River, Philippines. International Journal

of Environment and Geoinformatics (IJEGEO), 8(4): 507-513. doi. 10.30897/ijegeo. 908295

\begin{abstract}
Certain characteristics defining fluvial geomorphology have been linked with a wide range of ecological events that generate effects on the vital components of river systems. The Binahaan River in Leyte, Philippines, is important for irrigation and potable water distribution but little research has been conducted about its features. Our objective was to generate baseline data on the river by developing a model showing the geomorphic typologies of its $4.5 \mathrm{~km}$ portion. Using Rosgen's classification, we identified 12 typologies with the following key parameters: entrenchment ratio, width-to-depth ratio, sinuosity, slope, and channel material. Typology B5c - denoting moderate values for sinuosity and the entrenchment and width-to-depth ratios, and low slope range with sand as channel material - dominated the stretch. Data show that while some parts of the river are covered with silt/clay, sand occupied $57 \%$ of the identified typologies. Furthermore, many parts of the stretch were moderately entrenched and had high widthto-depth ratios. Sand mining generally disturbed the river and caused lower recovery potential for affected areas than the rest of the stretch. The identified typologies of the Binahaan River will be significant components for future research focusing on biodiversity and its relationship with the river's geomorphology.
\end{abstract}

Keywords: fluvial geomorphology, geomorphic typologies, geospatial modelling, recovery potential, sandmining

\section{Introduction}

Geomorphology plays an important role in influencing the state of both biological and abiological components within a certain area. Many studies have already tackled issues concerning this, along with its predominant effect on the floral and faunal communities in the ecosystem. In fact, geomorphic characteristics such as land elevation have already been proven to have an effect on the diversity of plants (Zhang, W., Huang, D W/ans $R$ et s1 ñर. Menteş et al., 2019; Aghayev and Mahmudov2019) and animals, particularly benthic macroinvertebrates (Qu, Xn rao, M., Shao, M., Li, D.F., and Cai, Q., 2007; Rashidin et al., 2019; Çelik and Gazioğlu, 2020).

According to Allan, J. and Castillo, M. (2007), geomorphological features of a river affect fluvial processes and functions. As such, any variations in geomorphology would generate a domino effect starting from the alteration of these processes, followed by disturbances in the ecological system and ultimately, changes in biodiversity. The physicochemistry of river waters under the influence of underlying geology has been identified to drive the distribution of macroinvertebrates among rivers and streams as cited in the study of Aguirre, A., Sanchez, M., and Blanco, J. in 2009.
Although there are different classification schemes proposed for the natural rivers and streams, the Rosgen's classification was used. This involves four levels of classification hierarchy where each level is dependent on the information derived from the previous level. It begins with geomorphic classification, followed by morphological descriptions. Third level involves an assessment of the stream's condition and the fourth level concerns with validation (Alsaberi and Oak, 2012). The main channel of the Palo sector of the Binahaan river was assessed using the five crucial characteristics, namely 1.entrenchment ratio, 2.width-to-depth ratio, 3.sinuosity, 4.slope, 5.channel material were obtained during subsequent field works on the site for river classification. Observations of stream and river systems provide insights into the sensitivity and consequence of change for a particular river assessed. Impacts of development, land use, and other anthropogenic activities are observed through the interaction of morphologic variables (Rosgen, 1996).

In this study, Rosgen's Classification of natural rivers was used to classify Binahaan river's geomorphic typologies, its sensitivity to disturbance, and its recovery potential. These data were utilized to construct geospatial models. River characterization is one step towards making policies that could give the river a longterm stability and function. The data and models generated from the geomorphology of the river could be used as bases for developing policies that will safeguard 
nearby communities affected by the river dynamics. In addition, there is a growing demand for the evaluation of fluvial ecosystems and this study could contribute to the discipline. Since the study demonstrates the status of the Binahaan river as defined by its geomorphic typologies, collected data could aid in future research as well as assist in predicting future events and implementing policies revolving around watershed preservation and flood management. As a baseline study, this creates a framework for comparison between similar stream types.

The Binahaan River System is part of a watershed which is economically important in the lives of Leyte communities as the river is the extraction point of the Leyte Metropolitan Water District. In the past years, several flood incidents were reported due to overflow of the Binahaan River. A Local Flood Early Warning System (LFEWS) has been put in place in certain Local Government Units in Leyte to manage disasters resulting from flooding. According to the GIZ (2012), the establishment of a Local Flood Early Warning System (LFEWS) is favorable to the reduction of disaster caused by floods and has been put in place by different Local Government Units (LGUs) in Leyte. In order to create a holistic program for these LGUs, the need to address the ecological criterion is necessary, which can be facilitated through geospatial modelling of the geomorphic typologies. Currently, the totality of the Binahan River is governed by different municipalities. Of these municipalities, only the Palo sector of the Binahaan River was given clearance to conduct the research. Hence, the baseline data on the geomorphological characteristics of the river must be generated for an effective policy formulation and implementation for the LGU.

\section{Materials and Methods Selection of Study Site}

The Binahaan river in Leyte, stretches out into the Binahaan watershed. However, due to climate change and ongoing sand mining in the Palo segment of the river, there have been incidents of flooding in the past which induced considerable damage to vegetation and properties (Neussner, O., Molen, A., and Fischer, T., 2008). This part of the river serves as a source of potable water for a large part of Eastern Visayas, as well as a site for sand-mining activities that extend to the endpoint of the Palo area. This section of the Binahaan river was determined using a distance-measuring application, MapMyWalk (MapMyWalk, 2018). The identified stretch was then divided into segments for efficient river parameter collection.

\section{Classification of River into Typologies \\ Entrenchment Ratio}

The required parameters were acquired with the use of a landslide and flood hazard map provided by the Mines and Geosciences Bureau - Region 8 (MGB-8) of the Department of Environment and Natural Resources (DENR). This geohazard map was georeferenced to match the World Geodetic System (WGS84), which was the coordinate reference system (CRS) used throughout the conduct of this study. QGIS 3.2.3, a free and open source geographic information system, and its Measure Line feature was used to acquire multiple lengths necessary for the computation of the parameters (QGIS, 2010). Flood-prone width was measured every 200 meters by creating segments across the river, with the lengths automatically calculated by said feature. This process was also followed for bankfull width measurement using a current map of the area from OpenStreetMap, a community-driven collaboration on the creation of an open data map of the world (OpenStreetMap, 2013). These measurements were then plugged into Equation (1):

$$
E R=\frac{W_{f p a}}{W_{b k f}}
$$

where ER: entrenchment ratio $\mathrm{W}_{\mathrm{fpa}}$ : width of flood-prone area $\mathrm{W}_{\mathrm{bkf}}$ : width of bankfull channel

\section{Width-to-Depth Ratio}

River depth was measured using depth sounding, for which the sounding line was comprised of a cementfilled bucket attached to a rope with a length of about 25 meters. As for the width of the river in each segment, the same method used in determining the bankfull width was applied. Equation (2) was used to derive the width-todepth ratio:

$$
W / D=\frac{W_{b k f}}{D_{a v g}}
$$

where $W / D$ : width-to-depth ratio $\mathrm{W}_{\mathrm{bkf}}$ : width of bankfull channel $\mathrm{D}_{\text {avg }}$ : mean depth of bankfull channel

\section{Sinuosity}

Total length for each segment was calculated by drawing a line parallel to the river's midline. For the total length of the stretch or stream length, individual segment lengths were summed. As for the straight line distance or valley length, a line was drawn connecting the two endpoints of the river stretch. These values were then used to compute for the river's sinuosity:

$$
K=\frac{L_{S}}{L_{v}}
$$

where $K:$ sinuosity

$\mathrm{L}_{\mathrm{s}}:$ stream length

$\mathrm{L}_{\mathrm{v}}$ : valley length

\section{Slope}

The uniform lengths of the river segments were taken as the distance between the segments' endpoints. The change in elevation, on the other hand, was calculated by subtracting the depths of the river at the two endpoints. The computation was accomplished using Equation (4):

$$
m=\frac{\Delta y}{\Delta x}
$$

where $m$ : the slope 
$\mathrm{x}$ : the distance between the segment's endpoints

$\mathrm{y}:$ the change in river elevation

\section{Channel Material}

Channel material data were acquired by collecting soil samples from both riverbanks per segment. Soil samples were stored in resealable bags before being subjected to microscopic analysis. A protocol by Attal, M. (2011) was used, wherein grain sizes were randomly chosen and measured to compute the median particle diameter $\left(D_{50}\right)$ for each collected sample, which is the defining factor in channel material classification. Grain size measurement was conducted using ToupView, a microscope camera control and image processing application (ToupTek, 2018). Final channel material classification was based on the Rosgen classification of streams (see Appendix).

\section{Construction of Geospatial Model}

The initial map outline used for all proceeding modifications and references were obtained from OpenStreetMap. With the use of GPS coordinates obtained from receivers, the Palo stretch was identified and an outline for the area was constructed using QGIS 3.2.3. The outline was then divided into segments to represent the intervals where parameter measurement took place. Each segment was given parameter data (slope, sinuosity, entrenchment, channel material, and depth) and classified into typologies. The classification

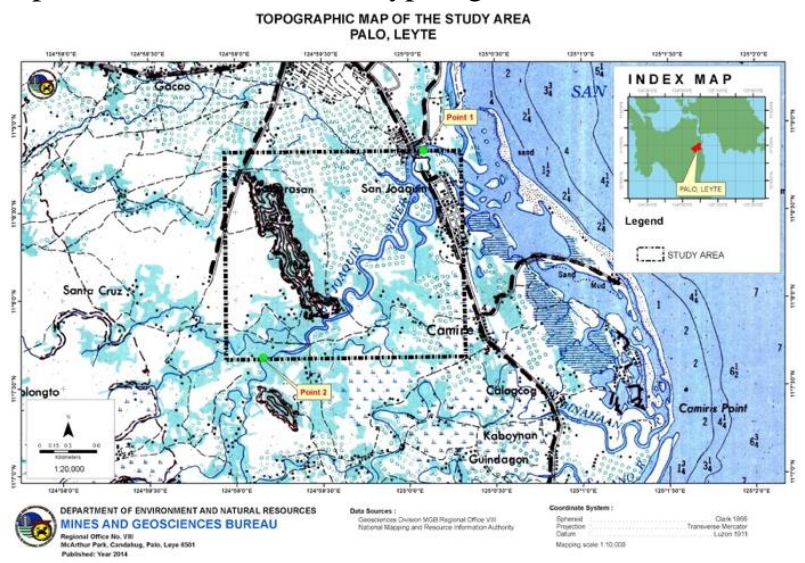

Fig. 1a. Topographic map of the identified 4.5-km stretch from Mines and Geosciences Bureau Regional Office 8

The Binahaan river (N $11^{\circ} 6^{\prime} 10.44^{\prime \prime}$ to $11^{\circ} 15^{\prime} 59.46^{\prime \prime} \mathrm{E}$ $124^{\circ} 45^{\prime} 38.05^{\prime \prime}$ to $\left.125^{\circ} 3^{\prime} 7.52^{\prime \prime}\right)$ plays a great economic role as it serves as a key source of irrigation and water distribution of the Leyte Metropolitan Water District of Region VIII (Philippine Information Agency, 2007). This water system that distributes potable water for several towns of the province. (Cayubit, R., 2017). In Figure 1b, a geohazard map of the study area is presented. The areas around the river are considered flood prone. It is possible that due to climate change and the ongoing sandmining, these incidents of overflowing signify the emerging need to evaluate the status of the river. To differentiate the segments according to their typologies, necessary river parameters were first accounted for. was based on the Rosgen Classification of Streams (Rosgen, 1994).

\section{Assessment of the River's Status}

To study the current status of the river, the United States Department of Agriculture's (USDA) summary for general characteristics of the Rosgen typologies was used. Evaluation of data focused particularly on recovery potential and sensitivity to disturbance (see Appendix). Geospatial models showcasing said characteristics and the ratings per typology were curated using QGIS 3.2.3.

\section{Results and Discussion}

The study aimed to develop geospatial models of the Binahaan River in Leyte in terms of its geomorphic typologies, sensitivity to disturbance, and recovery potential. The Rosgen classification system was used to determine the river's morphological arrangements at different points of the stretch. For this study, the Palo sector of the Binahaan river in Leyte, Philippines was chosen. The stretch, spanning approximately $4.5 \mathrm{~km}$ in length, was divided into 100-m segments wherein river parameter collection took place. Figure 1a shows a topographic map of the Binahaan river system, highlighting the portion that was evaluated in this research. The map was generated by the Mines and Geosciences Bureau Regional Office VIII for this study.

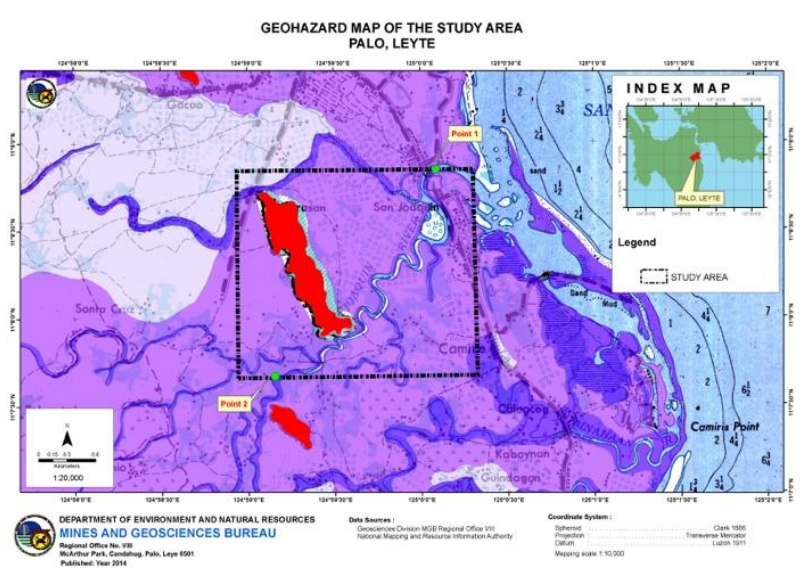

Fig. 1b. Geohazard map of the identified 4.5-km stretch from Mines and Geosciences Bureau Regional Office 8

The entrenchment ratio per segment was calculated by measuring the flood-prone and bankfull width using the Measure Line tool, as shown in Figures $2 \mathrm{a}$ and $2 \mathrm{~b}$, respectively. Based on Rosgen's Key to the Classification of Natural Rivers, the entirety of the stretch is moderately $(45.45 \%)$ to slightly entrenched $(30.3 \%)$ and has a width-depth ratio ranging from moderate to high (93.9\%). Figures $3 \mathrm{a}$ and $3 \mathrm{~b}$ demonstrate length measurement of an individual segment, as well as the acquirement of straight-line distance for the computation of the sinuosity. Results show that the stretch is highly sinuous, signifying that it meanders intensely along its length. The computed slope values for each segment collectively fit into the low slope range $(<0.02)$. 


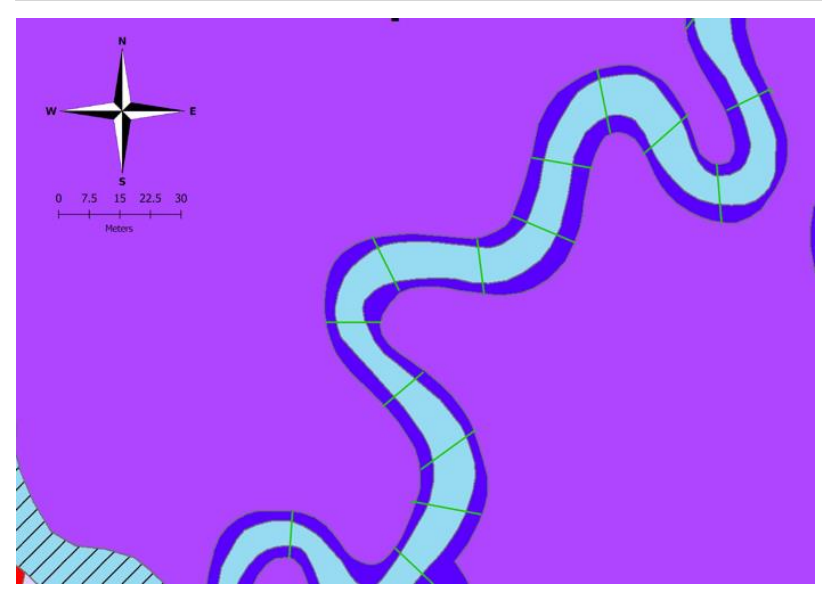

Fig. 2a. Flood-prone width measurement using a geohazard map from MGB-8

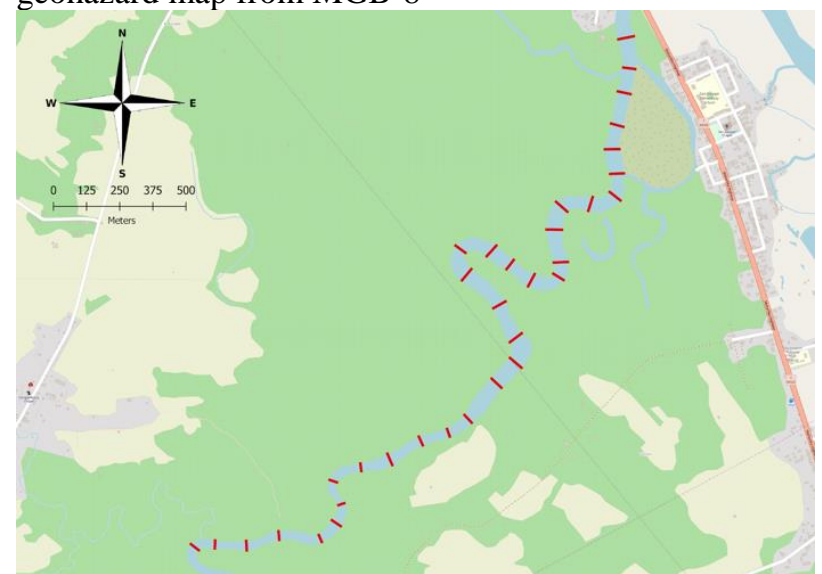

Fig. 2b. Bankfull width measurement using a map from OpenStreetMaps

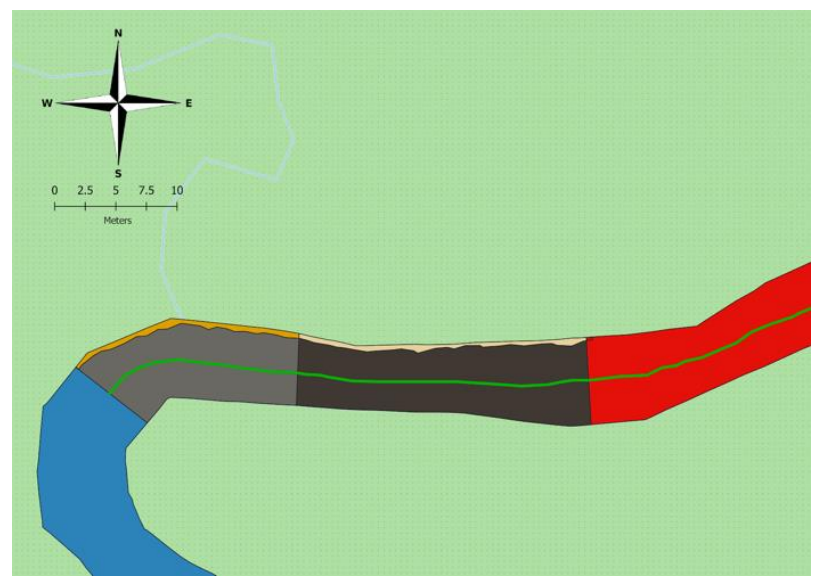

Fig. 3a. Length measurement of individual river segments

As for the channel material, intermediate axes of randomly selected grain particles of the samples were measured using ToupView. The samples were identified based on their resulting median particle diameters $\left(D_{50}\right)$ using Rosgen classification. Figures $4 \mathrm{a}$ and $4 \mathrm{~b}$ illustrate the process of getting the particle lengths. Similar to Moghaddas, N. F., Jalilvand, R., and Soloki, H. R.'s (2013) findings on the Sistan River morphology using Rosgen classification, the obtained data on the river's channel material was composed of sand and silt/clay.

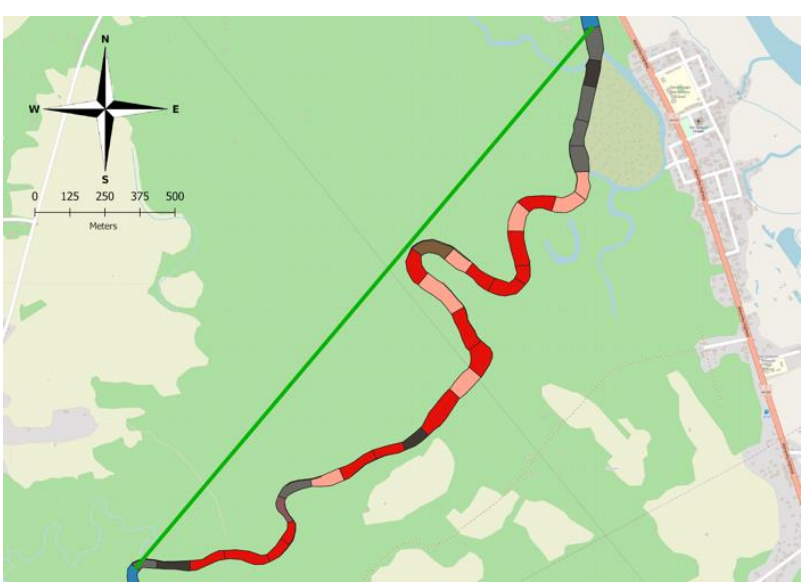

Fig. 3b. Acquirement of the straight-line or valley distance of the stretch

Sand occupied most of the banks and bed of the stretch, being the channel material of $57 \%$ of the created typologies. However, seeing that the Binahaan river is constantly exposed to anthropogenic activities and sandmining, it can be inferred that the aforementioned percentage may have been larger in the previous decades.

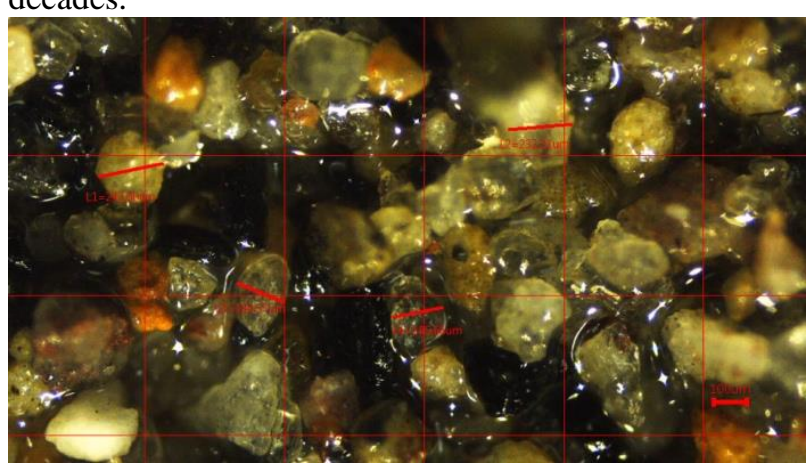

Fig 4a. Median size quantifications of sand samples

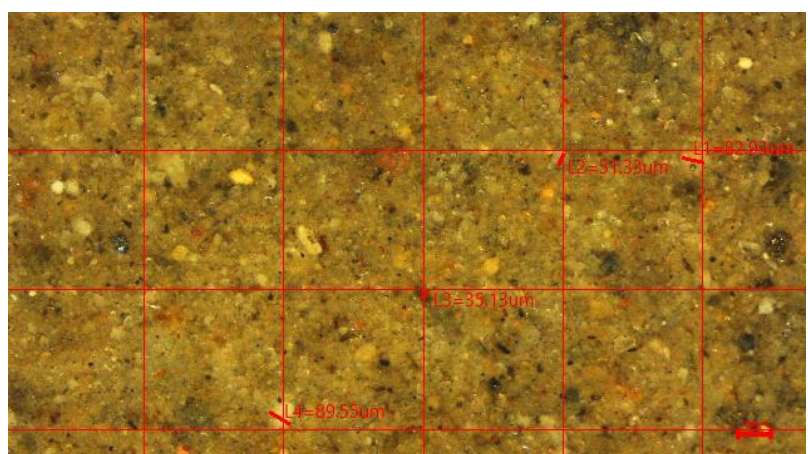

Fig. 4b. Median size quantifications of silt/clay samples

In total, 12 typologies were identified and formed. Figure 5 shows the preliminary map constructed via QGIS to indicate the differences in typologies, as well as to display the collected parameter data.

Figure 6 displays the distribution of the 12 typologies along the stretch. B5c is the dominating typology with $30.3 \%$, followed by B6c with $15.2 \%$. Category B in Rosgen classification denotes moderate entrenchment ratio, width-depth ratio, and sinuosity. 


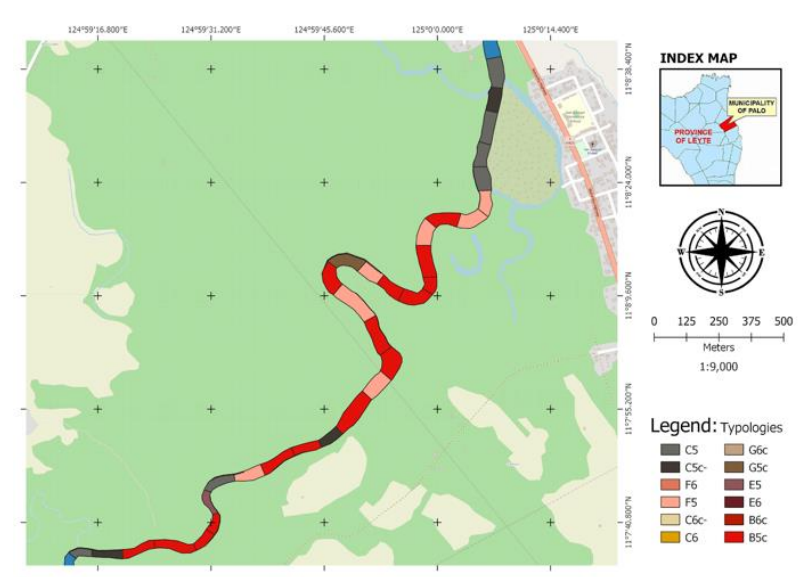

Fig. 5. Preliminary map of the $4.5-\mathrm{km}$ river stretch with color-coded typologies
Despite the fact that the Rosgen classification system only provides information about existing patterns and profiles, it can be assumed that river segments with the same general form also tend to have the same geomorphic processes. To describe the typical stream processes and behavior of the river, a summary of delineative criteria by the USDA - Natural Resources Conservation Service (NRCS) was applied. This summary uses a more finely resolved hierarchical criterion to stratify types and address general characteristics such as sediment supply, stream sensitivity, the potential for natural recovery, channel responses to flow regime change, and fish habitat potential (NRCS, 2007).

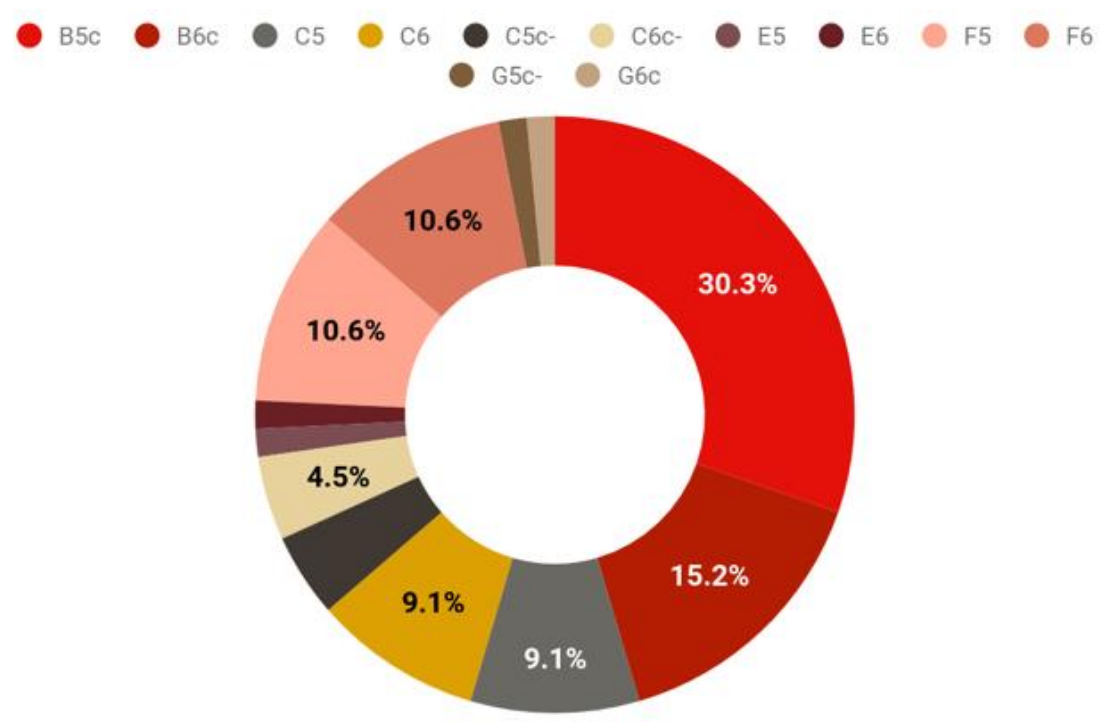

Fig. 6. Distribution of river typologies of the 4.5-km stretch.

The ratings per typology presented in the summary were plotted in Figures 7 and 8 to illustrate the variation in sensitivity and recovery potential along the stretch due to the changing of typologies. This data was also used in creating supplementary geospatial maps, as seen in Figures 9 and 10 .

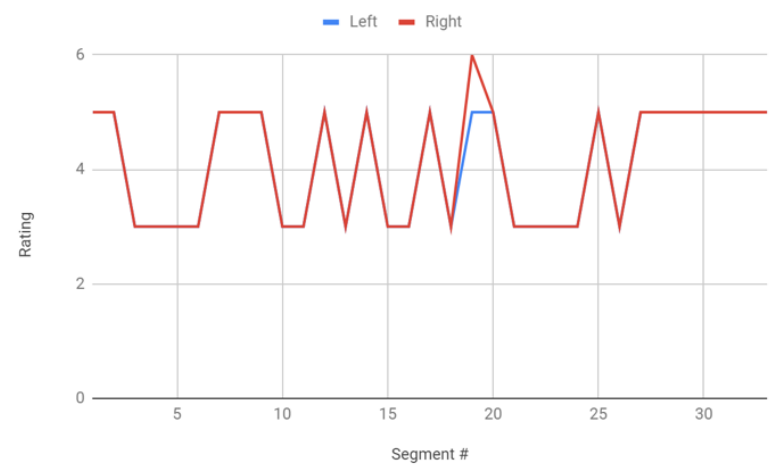

Fig. 7. Sensitivity to disturbance of the $4.5-\mathrm{km}$ stretch (1 - very low, 2 - low, 3 - moderate, 4 - high, 5 - very high, 6- extreme)

Judging from the line graph, the difference in channel material of both sides of the river bank had little to no influence on the river's sensitivity to disturbance, hence the overlap. Sensitivity rating frequently shifted from moderate to very high and vice versa throughout the whole stretch. From segment 26 onwards, the river portion nearest to the Palo community, it can be observed that the graph becomes stable at a sensitivity rating of very high. This trend coincides with the portion's identified typologies, C5 and C5c-, which are characterized by higher flooding risks indicated in high entrenchment ratios. This condition may be due to the area's accessibility for heavy sand-mining, and its role as a hub for drop-offs and transport of harvested sand. According to the Ojos Negros Research Group (2004), the impacts of sand mining, particularly for rivers, can be broadly classified into three categories: physical, water quality, and ecological. Large-scale extractions of streambed materials can cause major alterations in fluvial geomorphology, such as degradation of rivers and lowering of stream bottoms, which may lead to bank erosion and instability of structures (Ojos Negros Research Group, 2004). Gradual loss of structure stability negatively affects the area's capacity to shift back to its equilibrium after a certain disturbance, and 
this is reflected in the recovery potential of the river (Figure 5).

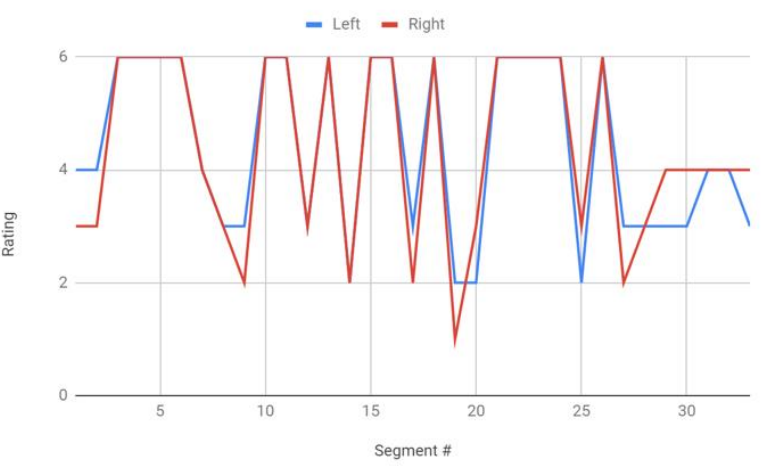

Fig. 8. Recovery potential of the $4.5-\mathrm{km}$ stretch (1 - very poor, 2 - poor, 3 - fair, 4 - good, 5 - very good, 6 excellent)

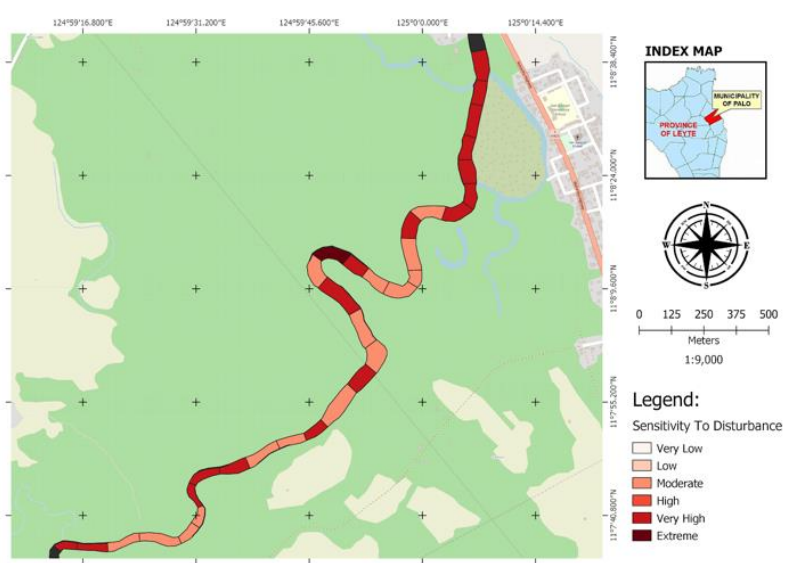

Fig. 9. Geospatial map of the 4.5-km stretch with colorcoded typologies (according to sensitivity to disturbance)

Recovery potential is defined as the efficiency of a river segment in assuming natural recovery once the cause of instability is corrected (NRCS, 2007). In contrast with what is seen in Figure 8, the type of channel material appears to affect recovery potential, with the typologies comprising of sand having lower recovery potential than the ones comprised of silt/clay. The graph reveals several high and low spikes, however, it can be seen that there is consistency from segments 2-7 and 27-33, wherein just one or two similar typologies exhibit greater range. This expansive uniformity suggests that these portions, aside from having homogenous typologies, have received the same treatment, either being undisturbed due to features i.e. protective vegetation or being exploited for resources such as sand.

The areas farthest from the Palo community have excellent recovery potential while those nearest are only rated poor to good. Despite this general trend, it can be observed that there are smaller reaches with distinct characteristics, which break the otherwise extensive length comprised of dominant typologies B5c and B6c. An example of which is segment 19 with typology G5c, defined by its instability with grade control problems and high bank erosion rates (NRCS, 2007). This description parallels with its being extremely sensitive and rating very poorly in recovery.

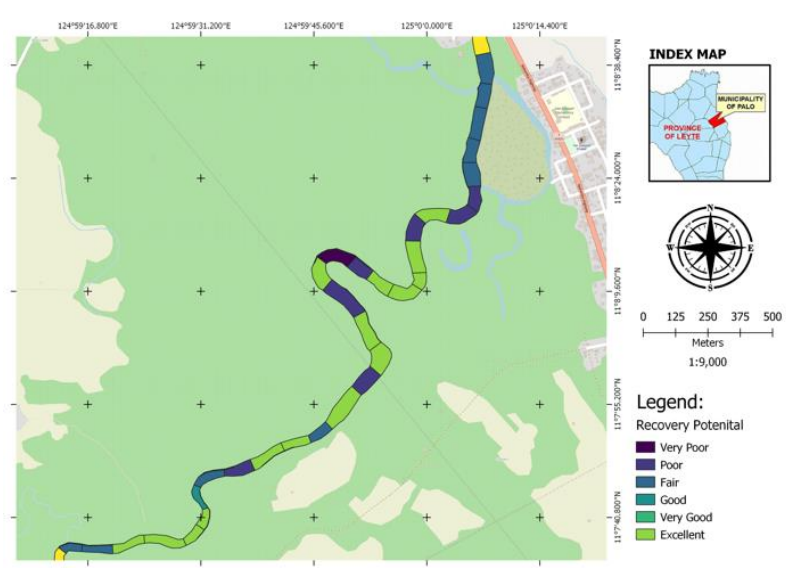

Fig. 10. Geospatial map of the 4.5-km stretch with colorcoded typologies (according to recovery potential)

\section{Conclusion}

A total of 12 Rosgen typologies were identified along the $4.5-\mathrm{km}$ stretch of the Binahaan river. The resulting geospatial maps indicate that while the majority of the stretch is stable, areas nearer to the community are characterized with values stipulating higher chances of flooding and lower protection from potential calamities, based on their sensitivity to disturbance and recovery potential. Albeit a result of natural phenomena, it is highly likely that these differences may also have been caused, or at least hastened, by the high amounts of sand-mining conducted along the area.

\section{Acknowledgements}

The implementation of this study was made possible through a grant from the Philippine Council for Agriculture, Aquatic and Natural Resources Research and Development of the Department of Science and Technology (DOST-PCAARRD), the agency that has been providing funds for research under the Biodiversity and Vulnerable Ecosystems Research (BiVER) Program.

\section{References}

Aghayev, A, Mahmudov, R. (2019). Analysis of the Kura River flooding in Azerbaijan territory in 2010 based on Hydrometeorologicall Observation and Remote Sensing, International Journal of Environment and Geoinformatics, 6(2), 205-212, doi. 10.30897/ijegeo.514468

Aguirre, A., Sanchez, M., and Blanco, J. (2009). Macroinvertebrate assemblages in gorgona island streams: spatial patterns during two contrasting hydrologic periods. Retrieved from http://www.scielo .org.co /scielo.php?script=sci_arttextandpid=S030435842009000200005

Allan, J. and Castillo, M. (2007). Stream Ecology. Retrieved from https://books.google.com.ph/books/ about/Stream_Ecology.html?id=4tDNEFcQh7ICandr edir_esc=y

Alsaberi, R. and Oak, R. (2012). Application of Rosgen Classification of Rivers to an Indin River - a Case Study. International Journal of Advanced Engineering Technology, 3, 1, 367-370. 
Cayubit, R. (April 2017). P200-M bridge to be constructed in Binahaan river. Manila Bulletin. Retrieved July 22, 2019 from https://news.mb. com.ph/2017/04/04/p200-m-bridge-to-be-constructed -in-binahaan-river/

Çelik, O., Gazioğlu, C. (2020). Coastline Difference Measurement (CDM) Method, International Journal of Environment and Geoinformatics, 7(1), 1-5.doi. 10.30897/ijegeo.706792.

Geilen, N., Jochems, H., Krebs, L., Muller, S., Pedroli, B., Van der Sluis, T., Van Looy, K., and Van Rooij, S. (2004). Integration of ecological aspects in flood protection strategies: Defining an ecological minimum. River Research and Applications, 20, 269283. doi: 10.1002/rra.777

GIZ (2012). Local flood early warning system. Environmental and Rural Development Program, GIZ GmbH. Manila, Philippines.

MapMyWalk. (January 2018). Retrieved August 14, 2019 from https://www.mapmywalk.com/

Menteş, E., Kaya, Ş., Tanık, A., Gazioğlu, C. (2019). Calculation of Flood Risk Index for Yesilirmak Basin-Turkey, International Journal of Environment and Geoinformatics, 6(3), 288-299.doi.10.30897/ ijegeo.661533

Moghaddas, N. F., Jalilvand, R., and Soloki, H. R. (February 2013). The investigation of the Sistan River morphology using Rosgen classification. Indian Journal of Science and Technology, 6(2). doi: 10.1007/s11434-007-0516-2

Neussner, O., Molen, A., and Fischer, T. (December 2008). Using geoinformation technology for the establishment of a local flood early warning system. German Technical Cooperation, Retrieved from https://www.researchgate.net/publication/242211078 _Using_Geoinformation_Technology_for_the_Establ ishment_of_a_Local_Flood_Early_Warning_System

NRCS Natural Resources Conservation Service. (August 2007). Rosgen stream classification technique Supplemental materials. United States Department of Agriculture. Retrieved on July 8, 2019 from https://directives.sc.egov.usda.gov/OpenNon WebContent.aspx? content $=17833$.wba

Ojos Negros Research Group. (2004). Impacts of sand mining. Sand Mining Facts, Retrieved March 1, 2019 from http://threeissues.sdsu.edu/three_issues_sand miningfacts01.html

OpenStreetMap. (December 2013). About. Retrieved July 22, 2019 from https://www.openstreetmap.org /about

PIA Philippine Information Agency. (April 2017). Landbank Tacloban adopts Binahaan river watershed project. Retrieved on September 29, 2018 from

http://archives.pia.gov.ph/?m=12andfi=p070417 .htmandno $=17$

QGIS. (March 2010). QGIS - The leading open source desktop GIS. Retrieved July 22, 2019 from https://qgis.org/en/site/about/index.html\#top

Qu, X. D., Cao, M., Shao, M. L., Li, D. F., and Cai, Q. (January 2007). Macrobenthos in Jinping reach of
Yalongjiang River and its main tributaries. The Journal of Applied Ecology, 18(1), 158-162

Rashidin, M., Javed, S., Liu, D., Tafsirojjaman, T. (2019). An Empirical Investigation on HydroMorphological Process of Surma River: Substantiation from North-East Zone of Bangladesh. International Journal of Environment and Geoinformatics, 6(1), 83-114, doi. 10.30897/ ijegeo.518468

Rosgen, D. L. (1996). Applied River Morphology. Wildland Hydrology, Pagosa Springs, CO.

Rosgen, D. L. (June 1994). A classification of natural rivers. Catena, 22(3), 169-199. doi: https://doi.org/ 10.1016/0341-8162(94)90001-9

ToupTek. (October 2018). ToupView. Retrieved August 20, 2019 from https://www.touptek.com/download /showdownload.php?lang=enandid=33

Walz, U. (2011). Landscape Structure, Landscape Metrics and Biodiversity. Living Reviews in Landscape Research, 5(3). doi: 10.12942/lrlr-2011-3

Zhang, W., Huang, D., Wang, R., et al. (2016). Altitudinal Patterns of Species Diversity and Phylogenetic Diversity across Temperate Mountain Forests of Northern China. doi: 10.1371 /journal.pone.0159995. 